\title{
NOTICIAS SACPER
}

\author{
SACPER News
}

REVISTA ARGENTINA DE CIRUGÍA PLÁSTICA 2019;25(2):100. HTTPS://DOI.ORG/10.32825/RACP/201902/0100-0100

\section{CONVENIO DE COOPERACIÓN}

Se celebró en la ciudad de Córdoba la firma del "Convenio Marco de Cooperación Institucional entre el Ministerio de Salud de la Provincia de Córdoba y la Sociedad de Cirugía Plástica de Córdoba". Estuvieron presentes los doctores Francisco J. Fortuna y Diego Cardozo (Ministro de Salud de la provincia y Secretario de Servicios Asistenciales, respectivamente), así como Nicolás Fagalde y Paul Nani (por la Sociedad de Cirugía Plástica). El convenio entra en vigor a partir de su firma, y durará dos años, prorrogables. Su finalidad es establecer lazos de cooperación recíproca y servir de marco para acuerdos relativos a puntos específicos, que se desarrollarán mediante anexos o protocolos de trabajo específicos.

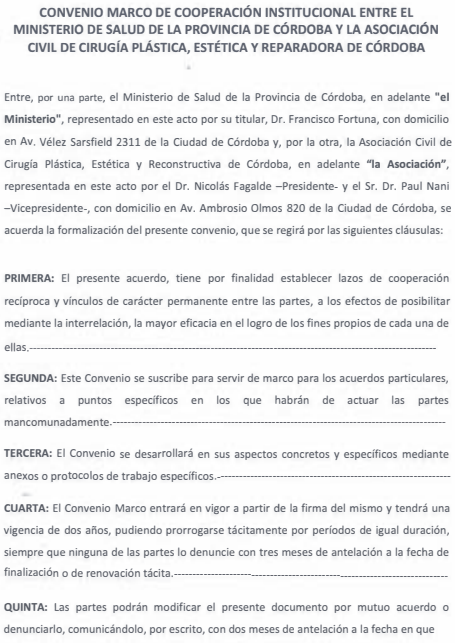

\section{REFLEXIONES SOBRE LA EXPERIENCIA}

- "La experiencia es un billete de lotería comprado después del sorteo"

- "La experiencia es un peine que te dan cuando te quedas calvo"

- "Los años enseñan muchas cosas que los días desconocen"

- "Los buenos resultados provienen de la experiencia, y la experiencia proviene de los malos resultados"

- "La experiencia es una maestra cruel, porque primero nos toma examen y después nos enseña"

- Y recuerda: "Antes de que el hierro enrojecido haya recibido su forma, el martillo debe haber conversado largo rato con el yunque. Esto es lo que se denomina EXPERIENCIA"
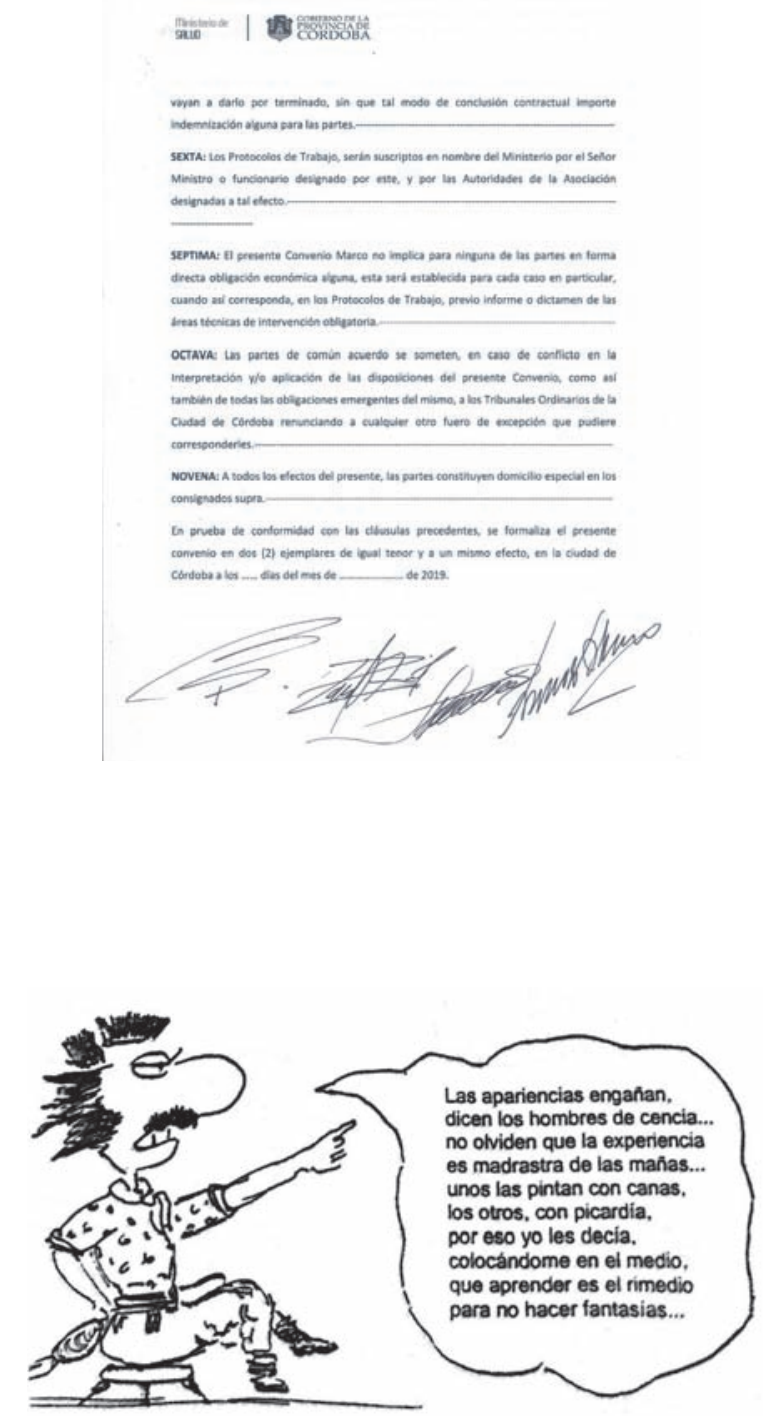